Jurnal At-Tibyan: Jurnal Ilmu Alqur'an dan Tafsir

Volume 6 No. 1, Juni 2021 (p. 110-127)

P ISSN 2442-594X | E ISSN 2579-5708

http://journal.iainlangsa.ac.id/index.php/tibyan

\title{
THE DEVELOPMENT OF THE LITERACY OF QUR'ĀNIC INTERPRETATIONS IN SUDAN: CRITICAL STUDY OF THE AL-TAFSĪR AL-TAUḤĪDĪ
}

\author{
Moh. Abdul Kholiq Hasan \\ Universitas Islam Negeri Raden Mas Said Surakarta, Indonesia \\ hasanuniversitas@gmail.com \\ \begin{tabular}{|l|l|l|}
\hline \multicolumn{2}{|c|}{ DOI 10.32505/at-tibyan.v6i1.1909 } \\
\hline Submitted: 02-09-2020 & Revised: 12-06-2021 & Accepted: 19-06-2021 \\
\hline
\end{tabular}
}

\begin{abstract}
This article aims to critically explain the method of al-Tafsìr al-Tauhī $\bar{\imath}$ by Hasan al-Turābī and its position amongst other thematic commentary theories. This study is a descriptive qualitative study by employing content analysis theory. The results indicate the trend of al-Tafsir al-Tauhid $\bar{\imath}$ in two meanings. The first is as a commentary paradigm which leans on the unity of man and the universe in the message of the God's revelation. The second is as the form of thematic commentary of al-Wahdah al-Maudu' 'iyyah model. Therefore, this commentary is more appropriately categorized into al-Tafsìr al-Mushafi bi alWahdah al-Maudū'iyyah. It has three systematic explanation in each surah including Khulāṣah Hady al-Sürah, Tartīl al-Ma'āni, and Umūm al-ma'āni. AlTurābī's ability to unite various related elements in his commentary is not only between verses or surahs but also between human life and all its activities with the universe in a bond of al-Qur'an guidance which is core to monotheism. This is the advantage it has and is a new method in commentary literacy in Sudan. In fact, the method of al-Tafsir al-Tauhid $\bar{\imath}$ generally becomes a framework for the whole civilization project of al-Turābī. However, there are some critics towards his commentary regarding rationality and rejection of several authentic hadiths which seem to leave riwāyah in the commentary of the Qur'an.
\end{abstract}

Keywords; Sudan, Literacy Tafsir, Hasan al-Turā bì, Tafsìr Al-Tauḥ̄ dì

\begin{abstract}
Abstrak
Artikel ini bertujuan untuk memaparkan secara kritis metode al-Tafsìr alTauḥ̄ dì karya Hasan al-Turābī dan posisinya di antara teori tafsir tematik lainnya. Penelitian ini bersifat deskriptif kualitatif dengan menggunakan teori analisis konten. Hasil penelitian menunjukkan trem al-Tafsìr al-Tauhīdì memiliki dua pengertian. Pertama; sebagai paradigma penafsiran yang berporos pada pentingnya kesatuan manusia dan alam semesta dalam pesan wahyu Tuhan. Kedua; sebagai bentuk tafsir tematik model al-Wahdah al-Maudū 'iyyah. Sehingga tafsir ini lebih tepat dikotegorikan dalam penyebutan al-Tafsir al-
\end{abstract}

Copyright @ 2021. Owned by the Author, published by Jurnal At-Tibyan: Jurnal Ilmu Alqur'an dan Tafsir. Articles with open access. License: CC-BY 
Muṣhafi bi al-Wahdah al-Maudū'iyyah. Dengan tiga sistematika penjabaran dalam setiap surah. Meliputi: Khulāșah Hady al-Sürah; Tartīl al-Ma'àni dan Umūm al-ma'āni. Kemampuan al-Turābī dalam menyatukan berbagai unsur terkait dalam penafsirannya, tidak hanya antara ayat atau surat, tetapi juga antara kehidupan manusia dan segala aktifitasnya dengan alam semesta dalam satu ikatan petunjuk al-Quran yang berinti kepada tauhid, adalah keunggulan yang dimilikinya dan merupakan metode baru dalam literasi tafsir di Sudan. Bahkan secara umum metode al-Tafsīr al-Tauh̆̄ dì ini menjadi kerangka berfikir bagi keseluruhan proyek peradaban al-Turābī. Kritik terhadapnya terkait rasionalitas dan penolakannya terhadap beberapa hadis sahih, hingga terkesan meninggalkan riwāyah dalam penafsiran al-Qur'ān.

Kata Kunci; Sudan, Literasi Tafsir, Ḥasan al-Turābī, al-Tafs̄ir al-Tauḥìdî

\section{Introduction}

Sudan is an Africa Continent countinent, a negihbour state to Egypt. It located at the southtren of Cairo. These two country share some similiarities; filling the majority of Islamic Sunni community people are dominnat, flowing with the Nile, taking Arabics as official lingual Franca. There several local spoken dilect. Therefore these countries also have similar culture and tradition, however, there is shrouded in differences between the countries. ${ }^{1}$

Historically, in past time, these similarities are exist because these countries were one government area. Both are part of the reign of ancient Egypt, British colonialism, and the reign of modern Egypt. ${ }^{2}$ Sudan became its own country only on January 1, 1956. Neverthenless, inspite of these similarities geographically and culturally, Sudan's country financial economy, community services, and development progress slowler than Egypt. This condition is felt by people who has lived in these two countries. ${ }^{3}$

Economic and political crises often grace the news regarding Sudan. Since the country broke away from Egypt until now. Sudan never seems to be free from turmoil. Among the peaks of the greatest turmoil that has ever occurred was the demonstration demanding the independence of the people of South Sudan in 2005. It culminated in the independence of South Sudan on July 9, 2011. ${ }^{4}$ But behind it all, it cannot be denied that Sudan, with its simplicity and the kindness of its people, continues to pay

\footnotetext{
${ }^{1}$ Ariski Aznor, "Kepentingan Mesir Menolak Meratifikasi Kesepakatan Cooperation Framework Agreement (Cfa) Mengenai Aturan Pengelolaan Sungai Nil," Jom Fisip Vol 2 No 2 Oktober 2015 53, no. 9 (1981): 1689-99.

2 A. Kumsa, "South Sudan Struggle for Independence, and It's Implications for Africa," RUDN Journal of Sociology 17, no. 4 (2017): 513-23, https://doi.org/10.22363/2313-2272-2017-17-4-513-523.

${ }^{3}$ Putri Cahyanti, “Analisis Konflik Sudan Dan Sudan Selatan," Journal of International Relations 3 (2017): 84-95, http://ejournal-s1.undip.ac.id/index.php/jihi.

${ }^{4}$ Wahiduddin, "Konflik Sudan Dan Jatuhnya Rezim Presiden Omar Bashir," Nady Al-Adab 17, no. 1 (2020).
} 
attention to the sector. Education, especially, related to Islamic studies. So don not be surprised if Sudan is one of the reference places to study for Indonesian students. ${ }^{5}$ In fact, many world-class Sudan prominent figures have inspired the development of the study of the Qur'an and Islam. This includes the development of Islamic da'wah in the country. ${ }^{6}$

Among them is Mahmoud Mohammed Taha, a controversial, the modern scholars was born that in 1909 in Rufa'ah, Sudan who was sentenced to death for being considered apostates on Friday, January 18, 1985. The Second Message is among of his famous works ${ }^{7}$ The next figure who was his student, Abdullah Ahmed An-Na'im, an Islamic and human rights from Sudan who lives in the United States and teaches at Emory University. ${ }^{8}$ Consequently, there were lineage of thought and concept between the teacher and his students, i.e. the urgency to revise the verses of Madaniyyah with Makkiyah which are considered contradictory one to another, particulary in terms of religious freedom thinking, gender equality, anti-slavery, and secularization. ${ }^{9}$

The Sudan Scholars Muffassir are the expert in thematic Qur'ān tafsir study, Umar Yusuf Hamzah, the professor of Qur'ānic study in Omdurman University and other university in Sudan, outlined his works, i.e. Ma'ālim al-Tarbiyah fi al-Qur'ān wa

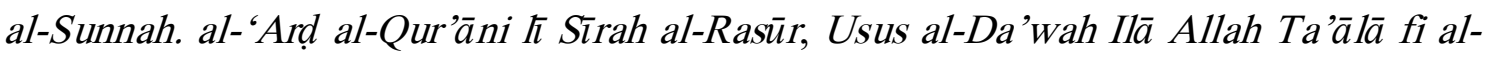
Qur'ān, Qabas min Sìrah al-Mustafa Șalla Allāh 'Alaihi wa sallām Fì Dau al-Qur'ān wa al-Sunnah, and Ma'ālim al-wah dah fi Thar̄q al-Ummah al-Islāmiyyah.

The next figure, who also considered phenomenal and controversial. ${ }^{10}$ the key figure of Islamic Sharia Law as pubic law in Sudan, he is Syaikh Hasan al-Turābī. His success in compromising between Islam and democracy has become an inspiration for many Islamic figures in the world. ${ }^{11}$ Many of his works have been published to be

\footnotetext{
5 Hayati, "Perbandingan Pendidikan Antara Negara Mesir Dan Sudan," Serambi Tarbawi Jurnal Studi Pemikiran, Riset Dan Pengembangan Pendidikan Islam 01, no. 02 (2013): 395-412.

6 Abdul Kadir, "Dakwah Dan Pembaharuan Pendidikan Islam Syaikh Ahmad Surkati," Jurnal Da'wah: Risalah Merintis, Da'wah Melanjutkan 2, no. 02 (2020): 1-20, https://doi.org/10.38214/ jurnaldawahstidnatsir.v2i02.54.

${ }^{7}$ Rasyidah Fathina, "Mahmoud Muhamed Taha: Redefinisi Konsep Nasakh Sebagai Pembentuk Syariat Humanis," Jurisdictie, 2012, 61-69, https://doi.org/10.18860/j.v0i0.1593.

8 Ahmad Taufiq, "Pemikiran Abdullah Ahmed An-Naim Tentang Dekontruksi Syari'ah Sebagai Sebuah Solusi," International Journal Ihya' 'Ulum Al-Din 20, no. 2 (October 2, 2018): 145, https://doi.org/10.21580/ihya.20.2.4044.

9 Tholkhatul Khoir, "Titik Temu Pemikiran Mahmoud Mohamed Thaha Dan Abdullahi Ahmed AnNa'im," International Journal Ihya' 'Ulum Al-Din 18, no. 1 (September 7, 2017): 65, https://doi.org/10.21580/ihya.17.1.1746.

${ }^{10}$ Many of Hasan al-Turābī's thoughts have caused controversy among Islamic academics. Among them, related to his opinion that allows women to become imams of male congregational prayers. On the condition that the woman is knowledgeable while there is no male congregation more pious than the woman. Al-Turābī also rejected the descent of Isa al-Masih which he considered an illusion of the thinking of the defeated. Denies some hadiths related to flies. And allow marriage with people of the book. View: Moh. Hatta, "Pemikiran Hukum Islam Hasan Al-Turabi," Darussalam: Jurnal Pendidikan, Komunikasi, Dan Pemikiran Hukum Islam 7, no. 1 (2015): 189-99..

11 W J Berridge and Hasan Islamist, "Reviews of Books The Spectre of Hasan Al-Turabi and Political Islam in Sudan” 89, no. May (2019): 398-401.
} 
discussed by academics. His works are mostly related to Islamic law, Islamic politics and a little related to the study of the Qur'an.

Syaikh Hasan al-Turābī works related to the Qur'ān is al-Tafsìr al-Tauhīd $\grave{\imath}$ which will be the object of this research. This figure is discussed because in addition to the reasons above, Hasan al-Turābī is also an actor and practitioner of his study of the Qur'an. ${ }^{12}$ He comments the works among the modernist interpretation trends which claim that the Qur'an is open to personal interpretation. ${ }^{13}$ Answering various problems of modern life. ${ }^{14}$ Even some of the reviewers responded with scathing criticism and considered anomaly thinking. ${ }^{15}$

There are several studies related to the work of Hasan al-Turābī. Generally about the renewal of ushul fiqh, ${ }^{16}$ Islamic law, ${ }^{17}$ and its influence on contemporary legal thought. ${ }^{18}$ As for the interpretation of asan al-Turābī, not much research has been done. Apart from that he is better known as an expert in Islamic law than a commentator, also because his works of interpretation are not widely known by academics when compared to his work in Islamic Law.

One of the most important studies related to the interpretation of Hasan alTurābī was carried out by Ibrahim Mohammad Zen. Discusses the importance of the book al-Tafsìr al-Tauhì di by Hasan al-Turābī as one of the doors of contemporary interpretation. The study also confirms that the interpretation of Hasan al-Turābī opens the opportunity for personal interpretation. ${ }^{19}$ The next research was carried out by Abdul Karim who substantially reaffirmed the position of al-Tafsīr al-Tauhīdī as a written interpretation to answer modern problems. ${ }^{20}$ Next is research by Muhammad Makmun Abha who criticizes the book al-Tafsir al-Tauhidi. Nevertheless, according to the author, some findings are less accurate regarding the data and conclusions. For example, it is related to the number of works of interpretation of al-Tafsr al-Tauhid $\bar{\imath}$ and the position of al-Tafsìr al-Tauhìd in terms of thematic interpretation among commentators. $^{21}$

\footnotetext{
${ }^{12}$ Cecep Supriadi, "Relasi Islam Dan Negara: Wacana Keislaman Dan Keindonesiaan," KALIMAH 13, no. 1 (March 31, 2015): 217, https://doi.org/10.21111/klm.v13i1.285.

${ }^{13}$ Ibrahim Mohamed Ibrahim, Esam Eltigani Mohamed and Zain, "Hasan Al-Turabi 's Approach to Qur ' ā Nic Exegesis," Intellectual Discourse, IIUM Press 22, no. Ifkkfjgriľlw[flfv'aa1 (2014): 53-71, http://journals.iium.edu.my/intdiscourse/index.php...

${ }_{14}$ Supriadi, "Relasi Islam Dan Negara: Wacana Keislaman Dan Keindonesiaan."

15 Abdul Karim, "Tafsir At-Tauhîdi Karya Hasan At-Turâbi: Selingkung Baru Dalam Tafsir," Hermeneutik 13, no. 1 (2019): 34, https://doi.org/10.21043/hermeneutik.v13i1.5553.

${ }^{16}$ Mas'adah, "Epistemologi Pembaharuan Usul Fikih Hasan Turabi," Jurnal Mahkamah 2, no. 1 (2017): 59, https://doi.org/10.25217/jm.v2i1.78.

${ }^{17}$ Hatta, "Pemikiran Hukum Islam Hasan Al-Turabi."

${ }^{18}$ Mira Novyanti, "Reformasi Ushŭl Fikih Menurut Hasan Al-Turâbî Dan Kontribusi Pemikirannya Terhadap Dinamika Pemikiran Hukum Islam Kontemporer" (INSTITUT AGAMA ISLAM NEGERI (IAIN) ANTASARI BANJARMASIN, 2017), http://idr.uin-antasari.ac.id/id/eprint/9121.

19 Ibrahim, Esam Eltigani Mohamed and Zain, "Hasan Al-Turabi 's Approach to Qur ' ā Nic Exegesis.”

${ }^{20}$ Karim, "Tafsir At-Tauhîdi Karya Hasan At-Turâbi: Selingkung Baru Dalam Tafsir."

${ }^{21}$ Muhammad Makmun-Abha, "Kajian Kritis Atas Kitab Al-Tafsīr Al-Tawhīdī Karya Hāsan AlTurābī," Jurnal Studi Ilmu-Ilmu Al-Quran Dan Hadis 15, no. 1 (2014): 2014.
} 
Further research was carried out by Ibrahim Mohamed Zain in his article entitled Al-Fan wa Qậāyā al-Hawiyyah al-Sudāniyyah: Qirāah Tăwiliyyah Fì Manhaj alTafsìr al-Tauhidì. Zain emphasized that the theory of al-Tafsìr al-Tauhìd is not just a paradigm of interpretation of the Qur'an but is a project of Hasan al-Turābī's thought and civilization in shaping the identity of Sudan. However, once again, this article does not specifically discuss al-Tafsīr al-Tauhīd but tends to Hasan al-Turābī's thoughts in the framework of the formation of Islamic identity in Sudan. ${ }^{22}$

Based on the above background, this article aims to critically describe the method of Hasan al-Turāb-'s al-Tafsìr al-Tauh̆ $\bar{d}$ and its position among other thematic commentaries. This research is descriptive qualitative by using content analysis theory. The main data is in the form of two volumes of al-Tafsì al-Tauhidt. The first volume was published by Dār al-Sāqi, Bairut, Lebanon in 2004. And the second volume was published by Dār al-'Arabiah li al-'Uhūm Nāsyinūn, Lebanon, in 2011. These two volumes are recognized in fact as works of interpretation of Hasan alTurā $\bar{b} \bar{\imath}$ with ignores some invalid information regarding the existence of the third volume of al-Turābis's commentary. ${ }^{23}$ Researchers hope that the results of this study can contribute to the development of the interpretation of the Qur'an in the archipelago.

\section{Ḥasan al-Turābī Brief Autobiogrphy}

Hasan 'Abdullāh al-Turābī is an Islamic figure and activist. Has a strong influence on the Islamization of Sudan and the Islamic world. ${ }^{24}$ Born on February 1, 1932, in Kassala, North Sudan. Little Al-Turābī received religious education from his religious family. His father was a judge and knowledgeable. Al-Turābī completed his undergraduate education at the University of Khartoum in 1995. He obtained his Master's degree at Oxford University in 1957. And he received his doctorate in 1964 at the Oksborn University of Paris. ${ }^{25}$

On his return from France, al-Turāb became a lecturer at the law faculty of the Khartoum University. However, in the same year, he entered politics and succeeded in becoming a member of the Sudan parliament and secretary-general of the Islamic Charter. In 1969-1977, Al-Turābī was imprisoned due to political policies at that time. Then from 1979 to 1982 Al-Turābī was appointed attorney general and chief advisor on legal and foreign affairs until March $1985 .^{26}$

Al-Turābī as leader of the Islamic National Front (NIF) political party, succeeded in becoming deputy prime minister and foreign minister in 1988. In 1996 he was named chairman of the Sudan national parliament. A high career flow and a position

\footnotetext{
${ }^{22}$ Ibrahim Mohamed Zain, "Al-Fan Wa Qaḍāyā Al-Hawiyyah Al-Sudāniyyah: Qirāah Tạwīliyyah Fī Manhaj Al-Tafsīr Al-Tauhidī," Al-Tajdîd 20, no. 39 (2016): 249-81.

${ }^{23}$ Makmun-Abha, "Kajian Kritis Atas Kitab Al-Tafsīr Al-Tawhīdī Karya Hāsan Al-Turābī."

${ }^{24}$ W. J. Berridge, Hasan Al-Turabi: Islamist Politics and Democracy in Sudan, Hasan Al-Turabi: Islamist Politics and Democracy in Sudan, 2017, https://doi.org/10.1017/9781316848449.

${ }^{25}$ Mas'adah, "Epistemologi Pembaharuan Usul Fikih Hasan Turabi."

26 Novyanti, "Reformasi Ushŭl Fikih Menurut Hasan Al-Turâbî Dan Kontribusi Pemikirannya Terhadap Dinamika Pemikiran Hukum Islam Kontemporer."
} 
that has power second only to the president-general Umar al-Bashir. Time goes on, and his interests change as well. The understanding between al-Turābī and the president ended in $2001 .{ }^{27}$ Feeling the president's interests were disturbed, Al-Turāb was finally thrown into prison on charges that seemed far-fetched. Al-Turābī with great patience and self-commitment continued to serve his sentence until his death. He died in house confinement on March 5, 2016. After being rushed to the hospital due to a heart attack. His funeral was attended by thousands of mourners from all walks of life.

Hasan al-Turābī is not only known as an accomplished politician but is also known as an Islamic scientist and academic with a broad perspective. With his qualified knowledge related to turāis, a religious tradition, and modern sciences, as well as his mastery of four languages, namely Arabic, French, English, and German, he can produce many works during his busy schedule. Among them are Tajdid al-Fikr alIslāmī, al-Asykāl al-Nāzimah Li Daulah Islāmiyyah Mu'àshirah, Qậāyā al-Wahdah wa al-Hurriyyah, Tajdìd Ușūl al-Fiqh, Tajdìd al-Dinn, Manhajiyyatu, al-Muștalahāt alSiyāsiyyah fi al-Islām, al-Siyāsah wa al-Hukm, al-Dīn wa al-Fan, al-Salāh 'Imād alDin, al-Īmān wa Atharuhu fi al-Hayāh, al-Harakah al-Islamiyyah; al-Tațawwur wa alNahj wa al-Kasb, and al-Tafsìr al-Tauhīdì. ${ }^{28}$ Hasan al-Turābī works mostly are a response to his life's struggle with a reality in the world, mainly related to his commentary book al-Tafsīr al-Tauhidī which can be said to be the peak of the intellectual and spirituality of Ḥasan al-Turābī

\section{The Cradle of Al-Tafsìr Al-Tauhīdî}

In the late $70 \mathrm{~s}$ and early $80 \mathrm{~s}$, there was a fundamental change in the religious thought of Hasan al-Turābī. Apart from personal factors, the significant development of the Islamic political movement in Sudan also influenced it. The climax was when Hasan al-Turābī entered the government system which provided an opportunity to realize the Islamization project in Sudan. The project is broadly manifested in a charter called "al-Wahdah al-Wataniyyah a'lā Tañqah al-Islām. A charter that emphasizes the need for national unity based on Islamic values. It was this charter that later gave birth to a great paradigm called al-Tafsì $r$ al-Tauhidit. ${ }^{29}$

The al-Tafsìr al-Tauhīd paradigm becomes the spirit in all scientific, thought and civilization projects carried out by Hasan al-Turābī. That is a paradigm that has the aim of uniting and bringing together those who are separated and scattered in one unified message of divine monotheism. ${ }^{30}$ To strengthen and support project alTauhidi, Hasan al-Turābi seems to need to derive the legitimacy of his thoughts from

\footnotetext{
${ }^{27}$ Hatta, "Pemikiran Hukum Islam Hasan Al-Turabi."

${ }^{28}$ Karim, "Tafsir At-Tauhîdi Karya Hasan At-Turâbi: Selingkung Baru Dalam Tafsir."

${ }^{29}$ Zain, "Al-Fan Wa Qaụ̄āyā Al-Hawiyyah Al-Sudāniyyah: Qirāah Tạwīliyyah Fī Manhaj Al-Tafsīr Al-Tauhidī.”

${ }^{30}$ Makmun-Abha, "Kajian Kritis Atas Kitab Al-Tafsīr Al-Tawhīdī Karya Hāsan Al-Turābī."
} 
the Qur'an, as many Islamic thinkers do its. ${ }^{31}$ Then came the weekly study of the Qur'an using the al-Tafsir al-Tauhidi method.

The study was officially started by Hasan al-Turābī in 1994/1415 AH. At first, it was only attended by his main colleagues from interdisciplinary experts. No more between 7-10 people. Among them are experts in the field of Islamic law, Islamic studies, and scientists. The study continues to grow and attract public attention. Finally, the study was not only attended by academics, but also the general public. The depth and breadth of knowledge and the ability of al-Turābī's oration, made the study of his interpretation get its place in academic circles. As a western graduate, al-Turābī was very open to differences of opinion and even harsh criticism. This can be seen in the dialogue method which is characteristic of the lectures of al-Tafsir al-Tauhidís study. ${ }^{32}$

According to Hasan al-Turābī's confession, there were at least two factors that made him interested in writing al-Tafsìr al-Tauhid. First, his anxiety when reading the translation of the Qur'an while still studying in the West. Where the Qur'an is presented in a partial understanding. Taken from here and there without a unified comprehensive meaning. According to Hasan al-Turābī, such an understanding was born from a lack of knowledge of the Arabic language. Such a partial understanding will certainly harm the understanding of the Qur'an. Second, the classical interpretations considered by al-Turābī have not been able to answer modern problems. Still partial, focusing on the meaning of the words and sentences of the Qur'an. So that the meaning of the Qur'an is exposed in a disjointed understanding, not in a unified whole. Besides, many of the classical interpretations are filled with israiliyat stories ${ }^{33}$ that can damage the understanding of the Qur'ān. ${ }^{34}$

In addition to the two factors above, there are other factors as mentioned by alTurābī in the preamble of his book. Namely, there was a request from his students and colleagues for discussion regarding the need for a new reading of the Qur'ān. A reading that can provide an understanding that can unite the surah in the Qur'ān and its verses in a single unit despite the various themes. Able to unite the Koran with modern life and scientific progress. Unite all children of the nation, both Muslims and non-

${ }^{31}$ Zain, "Al-Fan Wa Qaḍāyā Al-Hawiyyah Al-Sudāniyyah: Qirāah Tậ̄iliyyah Fī Manhaj Al-Tafsīr Al-Tauhidī."

${ }^{32}$ Hasan Al-Turābī, Al-Tafsīr Al-Tauhīđì, vol. 1 (Bairut, Libanon: Dār al-Sāqi, 2004), al-Tamhīd, ad.

${ }^{33}$ Israiliyat stories are stories attributed to the Children of Israel. Some of these stories can be accepted, but some are rejected. The scholars divide the story of Israel into 3 categories. First, it is accepted because the position of the history is authentic and its content does not conflict with the contents of the Qur'an and the Sunnah of Maqbullah. Second, it was rejected because the sanad is weak and contradicts the contents of the Qur'an and the Sunnah of Maqbullah. Third, neither accepted nor rejected. That is related to the story of Israel which is not rejected but there is no explanation from the Qur'an or Sunnah. Such as the detailed story of the names of ashahbul kahf, the types of animals that boarded the ship of the prophet Noah, the type of wood on the ship of the prophet Noah and others. Viewt: Muḥammad Abū Shuhbah, Al-Isrāiliyyāt Wa al-Maự u'āt Fì Kutub al-Tafsīr (Kairo: Maktabah al-Sunnah, 1987), 106-110.

${ }^{34}$ Al-Turābiā, al-Tafsìr al-Tauhidì, 6. 
Muslims in one bond of tolerance..$^{35}$ And the peak can unite the reality of human life, the universe in submission only to Allah Almighty. ${ }^{36}$

According al-Turābī, the Qur'ān is the book of life. Instructions for the life of all mankind, Muslim and non-Muslim. For this reason, according to Hasan al-Turābī, the chaos that occurred was the result of the separation of the instructions of the Qur'an from human reality. There are many readers, memorizers of the Qur'an, and readers of its interpretation. But just memorizing and reading to just get a blessing. Not to provide a life change. The essential solution is to understand the Qur'an as one unit and practice in everyday life. Because the loss of the blessing of the Qur'ān is when people separate the reading of the Qur'ān from the practice of real life. ${ }^{37}$ Departing from this paradigm, al-Turābī tries through his interpretation, al-Tafsìr al-Tauhidì , to present the instructions of the Qur'àn in a unified meaning that is comprehensive between the text and human life and the universe within the framework of the unity of Allah.

\section{The Profile And Method of Al-Tafsìr Al-Tauhīdì}

Around 2004-2005, when the author was still studying Masters in Sudan, he found the book al-Tafsìr al-Tauhīoti already printed and sold at Dār al-Sudāniyyah li alKutub. Published by Dār al-Sāqi, Beirut, Lebanon in its first chapter. Includes the interpretation of surah al-Fatihah to surah al-Taubah. With a total of 944 pages. Then in 2011, the same publisher reprinted the first juz of al-Tafsì al-Tauhī $\bar{\imath}$. The second chapter of 1344 pages, covering the interpretation of Surah Yunus to Surah alAnkabut, was published in 2011 by Dār al-'Arabiyah li al-'Ulūm, Beirut, Lebanon. The two juz of tafsir were completed in decades, and most of them were written while alTurābī was in prison.

The pinions claim that there is a third juz starting from surah al-Rum ending to surah an-Nas which has not yet been published. ${ }^{38}$ But such claims have not been clarified adequately according to the author's knowledge. Because other data explain that al-Turābī died before completing his commentary until 30 juz. ${ }^{39}$ This data confirms that al-Turābī only bequeathed two volumes of his commentary until his death.

Hasan al-Turābī in al-Tafsìr al-Tauhidî, interprets the Qur'ān according to the order of the manuscripts as is generally the case with scholars. It starts with a preamble that explains his ideas about al-Tafsìr al-Tauhīd and its working pattern in the interpretation of the Qur'ān. Al-Turābī with his idea of al-Tafs̄̄r al-Tauhidì, wants to emphasize the unity of the theme of the Qur'ān as the book of life. The various reference, asbabun nuzul, the different themes of the discussion of the Qur'an, and its

\footnotetext{
${ }^{35}$ Zain, "Al-Fan Wa Qaḍāyā Al-Hawiyyah Al-Sudāniyyah: Qirāah Tạwīliyyah Fī Manhaj Al-Tafsīr Al-Tauhidī."

${ }^{36}$ Al-Turābiā, 7-9.

37 Al-Turābiā, 10-12.

${ }^{38}$ Makmun-Abha, "Kajian Kritis Atas Kitab Al-Tafsīr Al-Tawhīdī Karya Hāsan Al-Turābī."

39 'Ali Jabaly, “Al-Fikr 'Inda Al-Turābiā; Qirāah Fī Muqaddimah al-Tafsīr al-Tauhidī,” 2019, https://omran.org/ar/الفكر _التوحيدي_عند_الترابي?language=en.
} 
descent over a long time, according to Hasan al-Turābī, are not the reasons for the partial understanding of the Qur'an. Rather, it must be understood and presented in a unified theme that is interrelated like a string of tasbih seeds. It is hoped that the Qur'an will be able to answer the problems of modern society following the sense of risk and intelligence of its readers.

As a commentator rationalist, al-Turābī seems to put a high priority on rational ability in interpretation and rejects narrations that he considers unreasonable. This can be seen in his interpretation from beginning to end. In fact, on several occasions, he emphatically rejected several authentic hadis, even though Imam al-Bukhari narrated them in their authenticity. ${ }^{40}$ Al-Turābī also did not want to be bound by the opinion of the commentators previous. Moreover, just repeating existing opinions. On the other hand, it is not uncommon for al-Turāb to attack these opinions. Especially related to rigid classical thoughts and taqlid. A trend of renewal was carried out by reformers of religious thought such as Rashid Ridua ${ }^{41}$ and Ibn 'Ashr in his commentary. ${ }^{42}$

Al-Turābī in his systematic interpretation generally divides into three groups of discussion in each letter. First; Khulāṣah Hadyi al-Sūrah (خلاصة الهدي السورة). Contains the general profile of the letter to be interpreted. Such as the explanation of the name of the surah, the primacy of the surah, Makkiyah-Madaniah, and asbabun nuzul, the correlation of the surah with the surah before and after it. General explanation related to the core content of the surah in a unified presentation that is interrelated. Second; Read carefully the meaning of the Qur'ān (Tartīl ma'ānil ترنيل معاني). Contains interpretations related to verse by verse. By revealing the content of meaning related to the interpreted verse. Among them are related to the meaning of vocabulary, qira'ah, law, opinions of scholars, the context of place, time, and social society. But still under discussion according to the needs of the verse and not long-winded. To facilitate understanding, al-Turābī grouped the verses in the language into certain interrelated groups. Third; General meaning ('Umūm al-ma'āni/عموم المعاني ). Is a kind of summary of the explanation contained in the Tartīl ma'âni. Contains a global explanation covering the entire meaning of the verse in a unified theme that is interrelated. By not forgetting to actualize the meaning of the verse in people's lives as an inseparable unit.

The three terms above are used by al-Turāb to group several verses which are considered to have one theme in a letter. Therefore in one letter, there can be several Tartīl ma'āni and 'Umm al-ma'āni. Depends on the need when interpreting the

\footnotetext{
${ }^{40}$ Al-Amin Haāj Muhammad AḤmad, Munāqasyah Al-Hādìiah Li Ba'd Afkār Al-Duktūr Al-Turābiā (Makaz al-Shaf al-Iliktruni, 1995), 147.

${ }^{41}$ Moh. Abdul Kholiq Hasan, "Freedom Of Religion In Rashid Rida' S Rasyid Ridha and Al Manar Tafsir Freedom of Religion in Perspective of Rasyid Ridha' s Tafsir," Advances in Social Science, Education and Humanities Research (ASSEHR) 137, no. Icqhs 2017 (2018): 56-59, http://creativecommons.org/licenses/by-nc/4.0/.

${ }^{42}$ Moh. Abdul Kholiq Hasan, "Interfaith Tolerance and Its Relevance to the Indonesian Diversity: A Study on Ibn 'Āshūr's Al-Tahrīir Wa Al-Tanwīr," Ulumuna 22, no. 2 (2018): 333-62, https://doi.org/10.20414/ujis.v22i2.301.
} 
letter. ${ }^{43}$ However, it should be noted that in the use of these three terms, al-Turābi sometimes looks inconsistent. For example, when interpreting Surah al-Fatihah. The terms used are only Khulāṣah Hady al-Sürah and Tartīl ma'āni without 'Umūm alma'ani. $^{44}$ In fact, according to the author, it is very possible to give the general meaning of Surah al-Fatihah. In addition, al-Turābī's inconsistency is also seen when he uses the term Ijmà làt al-ayāt to replace the term 'Umīm al-ma'ānits however the two terms are not much different in meaning.

Hasan al-Turābī argues, that in understanding the Qur'ān, a commentator must understand the Qur'ān by the meaning of words that were popular at the time of the revelation of the Qur'ān. ${ }^{46}$ This is following the rules of interpretation which state that "It is obligatory to understand the word of Allah based on popular Arabic sayings, not strange, weak or evil". ${ }^{47}$ A commentator must also be committed to following the terms of the original sharia. Then base his interpretation on the explanation of the Prophet Muhammad, which is contained in the hadith and the history of his life with the Qur'an. Based on the reference, asbabun nuzul, and the social life of society and the beginning of Islamic society. ${ }^{48}$ Notice and understand the differences between words. Both in 'urf and fiqh. ${ }^{49}$ It is as if al-Turābī confirmed the theory that there are no complete synonyms in the Qur'ān. ${ }^{50}$

Based on the description above, it can be said that the interpretation of the Hasan al-Turābī model is something new in tafsir literacy in Sudan. Because the interpretation in Sudan at that time, in general, was still dominated by the classical tafsir method. A reality that prompted Hasan al-Turābī to give birth to his work called al-Tafsir al-Tauhidi, as an answer to the lack of interpretation in Sudan at that time. ${ }^{51}$ But is it true that the interpretation method of al-Tafsì $r$ al-Tauhi $\bar{d} \bar{\imath}$ is something new in the thematic interpretation theory? Or is it part of the thematic interpretation that has been discussed by scholars?.

\footnotetext{
${ }^{43}$ Sebagai contoh, Al-Turābī, Al-Tafsīr Al-Tauhī dì, 2004, 39-43, 44-50.

${ }^{44}$ Al-Turābī, Al-Tafsìr Al-Tauhīđì, 14-18.

${ }^{45}$ Al-Turābī, Al-Tafsìr Al-Tauhī đì, 356.

${ }^{46}$ Al-Turābī, 4.

${ }^{47}$ Moh. Abdul Kholiq Hasan, Kaidah Kaidah Tafsir Al-Qur'ān (Sukoharjo: EFUDE PRESS IAIN Surakarta, 2013), 64.

${ }^{48}$ Sebuah landasan penafsiran yang tidak hanya menyandarkan kepada teks asbabun nuzul secara mikro, tetapi memperluas pandangan secara macro dengan mengaikan kontek sosio-historis sejarah turunnya al-Qur'ān. Lihat: Munawir, "The New Development Of Ulumul Qur' an ( The Methodological Studies of Asbab Al- Nuzul )," Jurnal At-Tibyan: Jurnal Ilmu Alqur'an Dan Tafsir 5, no. 1 (2017): 7489, https://doi.org/10.32505/tibyan.

49 Sebagai contoh: Al-Turābī, Al-Tafs̄ì Al-Tauhīdî, 2004, 103-104, 116-117. Hasan Al-Turābī, AlTafsìr Al-Tauhīđì, Vol. 2. (Bairut, Libanon: Dār al-'Arabiah li al-'Ulūm Nāshirūn, 2011), 979-982, 100810011.

50 Ubaid Ridlo, "Sinonim Dan Antonim Dalam Al-Quran," Jurnal Al Bayan: Jurnal Jurusan Pendidikan Bahasa Arab 9, no. 2 (2018), https://doi.org/10.24042/albayan.v9i2.2253.

${ }^{51}$ Al-Turābī, Al-Tafsīr Al-Tauhì đì, 2004, 4-5.
} 


\section{The Relationship Al-Tafsīr Al-Tauhī đì and Al-Maudī 'i'}

Al-Tafsìr Al-Tauhìdíasan by al-Turābī, as the name implies, is intended to present the interpretation of the Qur'ān as a single unit, even though it has various discussions and themes. A unity between the reading and the text, between words and words, between sentences and sentences, between verses and letters. Not only that, the unity of the Qur'ān with the reality of life and the universe is a unity that must be considered when understanding the Qur'ān.

According to al-Turābī, al-Qur'ān as a book of guidance for all humans, both Muslims and non-Muslims, must be able to provide answers throughout the ages. The Qur'àn was not only revealed for a certain period but was intended for the Day of Judgment. It is a must how the Qur'àn can dialogue with the period in which it is read. So that all humans and the universe unite in one frame of evidence for the oneness of God. ${ }^{52}$ In other words, al-Turābi through his commentary wants to show the need for an understanding of the unity between the text of the Qur'àn, the universe, and Allah Almighty.

For the al-Turābī, al-Tauhīd method is not merely theoretical disc. But it is an invitation from the Qur'ān which is used as a driving model in his entire life. Understanding the Qur'ān and al-Sunnah as a unit that cannot be separated. Uniting the instructions of the Qur'ān with the Sunnah. The Qur'ān is a revelation that will not dry up to be explored. And the life of the Messenger of Allah is like human life, eating, drinking. And life as a servant of God, prophet, and messenger, and leader of the people. As-Sunnah as the second source after the Qur'àn, but cannot be separated from the Qur'ān. And there is no contradiction between the Qur'ān and the Sunnah. By making the Qur'ān as the Sunnah to follow. ${ }^{53}$

Al-Turābi actualizes the meaning of al-Tauhī $\bar{\imath}$ in broad scope, as far as reachable. Including the meaning of monotheism in the sense of unity between the text of the Qur'ān and the universe. How the universe that God has subjected to humans, can increase their faith in Al-Turābī. For this reason, al-Turābī criticized some commentators who ignored the meaning of the natural laws contained in the universal verse. Or do not give a sufficient portion in interpreting it. They should link the revelation verses with the verses of human life and the rise of science in the interpretation of the Qur'ān. ${ }^{54}$

Al-Turābī seemed to want to emphasize to all readers that the meaning of monotheism in question, is not the meaning that has been understood by most people. According to Al-Turābī, monotheism is defined as a form of unity between the Qur'ān as God's revelation and human life. And all that exists belongs to Allah Almighty. Unite all mankind in one common goal on earth, as caliph to prosper the earth with love and peace and tolerance. ${ }^{55}$

\footnotetext{
${ }^{52}$ Al-Turābī, Al-Tafs̄ir Al-Tauhī dì, 2011, 12-19.

${ }^{53}$ Al-Turābī, Al-Tafsìr Al-Tauhī dì, 2004, 9.

${ }^{54}$ Al-Turābī, 11-12.

${ }^{55}$ Al-Turābī.
} 
According to al-Turābī, the Qur'ān will not be able to embrace life, unless it is understood as a comprehensive unit. Because in fact, the main basis of religion is monotheism or unity. And the Qur'ān is the source of unity. Uniting the world and the hereafter, between the spirit and the body, between material and non-material, between worship and work, between the world and religion. In a unity that can not be separated from each other. Regarding this, al-Turābī said:

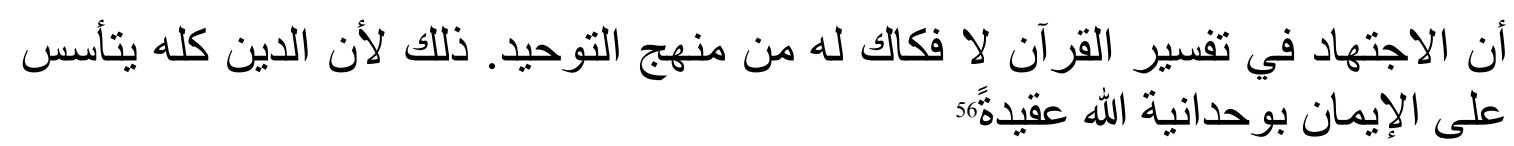

"Indeed, Ijtihad in the interpretation of the Qur'ân cannot be separated from the Manhaj of Tawhid. Because the basic principles of all religions are based on faith in the oneness of Allah", then Al-Turābī continued:

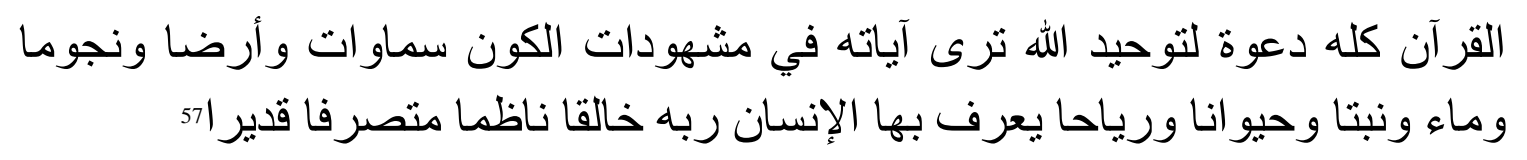

“The whole of the Qur'ānic content invites to tauhīdullāh. It's acknowledged throughout, earth, stars, water, plants, animals, and wind. With it, people know their Lord as Creator, Regulator, and Ruler".

The understanding of at-Tafsìr at-Tauhīd $\bar{\imath}$ above when viewed from the existing theory still has the connection with the theory who was introduced by Muhammad alHijāzi within al-Wahdah al-Maudu'iyyah. Where a commentator unites related verses in a particular theme that complements each other. ${ }^{58}$ Some scholars such as Muhammad al-Gazali call it al-Tafsìr al-Maudū'i. That is the effort of interpreting a letter as a whole, by showing the main picture or main purpose of a letter from beginning to end. In a bond of exposure that binds each other. The beginning of the letter can be seen as the beginning of the end of the letter, and the end of the letter as an explanation of the beginning of the surah. So that a letter is seen in one central theme that is mutually binding, even though the latter actually includes several diverse themes. ${ }^{59}$

The thematic interpretation models emphasize efforts to present a world view or the main purpose or main point of a surah to be discussed. Or what is known

\footnotetext{
${ }^{56}$ Al-Turābiā, Al-Tafs̄ì Al-Tauhì diā, 2011, 7.

${ }^{57}$ Al-Turābiā, 13.

${ }^{58}$ Muhammad Irfan Helmy, "Kesatuan Tema Dalam Al-Qur'ān (Telaah Historis-Metodologis Tafsir Maudhu'iy)," Jurnal Ilmu Ushuluddin 19, no. 2 (2020): 64-80, https://doi.org/http://dx.doi.org/10.18592/ jiiu.v19i2.3589.

${ }^{59}$ Wardah Nadhirah, “Hermeneutika Al-Qur'ān Muhammad Al-Ghazali (Telaah Metodologis Atas Kitab Nahwa Tafsir Maudhu'i Li Suwar Al-Qur'ān Al-Karim)," Jurnal Studi Ilmu-Ilmu Al-Qur'ān Dan Hadis 15, no. 2 (2016): 237, https://doi.org/10.14421/qh.2014.15203.
} 
as agrā $d$ verse or surah. ${ }^{60}$ Then make other verses related to the surah in a correlational bond or munāsabāt. ${ }^{61}$ For this reason, the relationship between thematic interpretation and 'science of al-munāsabāt is very close. Especially related to the thematic per surah or known as al-Tafsìr al-Maudū'i $\hbar_{\grave{l}}$ al-Sürah. ${ }^{62}$

The scholars try to distinguish between the al-Wahdah al-Maudüiyyah and the al-Tafsir al-Maudu' 'i. ${ }^{63}$ Where al-Tafsir al-Maudu' 'i is more related to certain themes that will be discussed by an interpreter. By collecting the theme verses to be discussed. Meanwhile, al-Wahdah al-Maudū'iyyah, in essence, is a bond munāsabāt or a binding correlation between one verse to another verse or one surah to another in a certain theme point. In other words, al-Tafsìr al-Maudu $\bar{u}^{\prime} i$ departs from the theme determined by the commentator who wants to be discussed. ${ }^{64}$ While al-al-Wahdah alMauiyyah departs from the theme contained in a letter that wants to be discussed. The theme was born from the verses discussed, not from outside the manuscript.

Based on the explanation above, it can be concluded that the method used by Hasan al-Turābī in his interpretation of al-Tafsìr al-Tauhī dì in the theory of thematic interpretation, is categorized as al-Tafsìr al-Mushafí ${ }^{65}$ bi al-Wahdah al-Maudū 'iyyah. It is said to be al-tafsìr al-muș hafi because the interpretation of al-Turāb is still bound by the order of verses and suras in the al-Qur'ān manuscripts. Starting from surah alFatihah to al-Ankabut. ${ }^{66}$ Meanwhile, it is called bi al-Wahdah al-Maudū'iyyah, because, in the explanation of his interpretation, al-Turābī uses a pattern of uniting related verses in one particular theme of a letter being discussed.

Al-Turābī's method of interpretation is actually not new. Many classical scholars have alluded to the importance of such an interpretation model. Even some of them have practiced the interpretation of the Qur'ān. ${ }^{67}$ In addition, the mention of alTurabi's interpretation as al-Tafsìr al-Tauhī $\bar{\imath}$ is not a new thing. Long before, in 1980

${ }^{60}$ Muhammad Al-Ghazāli, Nahwa Tafs̄ir Al-Maudhu'i Li Suar Al-Qur'ān (Kairo: Dār al-Syurūq, 1995), 5-6.

${ }^{61}$ Miftah Khilmi Hidayatulloh, "Konsep Dan Metode Tafsir Tematik (Studi Komparasi Antara AlKumi Dan Mushthofa Muslim)," Al-Bayan: Jurnal Studi Ilmu Al- Qur'an Dan Tafsir 3, no. 2 (2019): 130-42, https://doi.org/10.15575/al-bayan.v3i2.4116.

${ }^{62}$ Musțafa Muslim, Mabāḥith Fì Al-Tafsìr Al-Mauḍū 'i (Damaskus Syiria: Dār al-Fikr, 2000), 57.

${ }^{63}$ Muḥammad bin Sālim Bazmul, Tahrīr Fì Al-Tafsìr Al-Mauḍù 'i Wa Al-Wahdah Al-Mauḍu 'iyyah Li Al-Surah (Saudi Arabia: Kuliyyah al-Da'wah wa Ushuluddin Jamiah Ummul Qura, n.d.), 99., https://www.radiosunna.com/uploads/6/6/1/7/6617650/تحرير_التفسير_الموضوعي_و الوحدة_الموضوعية.pdf.

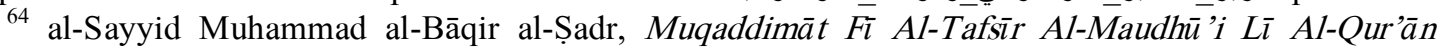
(Kuwait: Dār al-Taujīh al-Islāmi, 1980), 19.

65 Actually the mention of al-Mushafi (according to the order of the manuscripts), can also be referred to as al-Maudi'i (according to the location of the order of the verses of the Qur'ān in the manuscripts) which is the opposite of the word al-Maudhuā'i. View: MuHammad al-Gazāli, Naḥwa Tafsìr Al-Maựu'i Li Suar Al-Qur'ān (Kairo: Dār al-Syurūq, 1995), 5. Al-Shadar calls it the term alTafsiār al-Tajzi'i (partial), because the interpretation of the verses of the verses according to the order of the Qur'an is interpreted partially, not as a unit that is mutually bound by other verses of the same theme. View: al-Sayyid Muhammad al-Bāqir al-Ṣadr, Muqaddimāt Fì Al-Tafsìr Al-Maudhō'i Lì AlQur'ān, 10.

${ }^{66}$ Al-Turābī, Al-Tafsìr Al-Tauhī đì, 2011.

${ }^{67}$ Bazmul, Tahn̄r Fì Al-Tafsìr Al-Mauḍūi Wa Al-Wahdah Al-Maudūiyyah Li Al-Surah, 70-73., Helmy, “Kesatuan Tema Dalam Al-Qur'ān (Telaah Historis-Metodologis Tafsir Maudhu'iy).” 
or ten years before the birth of al-Tafsir al-Tauhi $\bar{c} \hat{\imath}$ in 1994, the tram was introduced by a reformer from Najaf, Iran, al-Sayyid Muhammad Bāqir as-Sadr. In his book Muqaddimāt fi al-Tafsir al-Maudū'i li al-Qur'ān, a work that is considered a pioneer in introducing al-Tafsir al-Maudu'i. Sadr divides the model or direction of interpretation into two categories. Namely al-Tafsr al-Tajzi'i and al-Tafsr al-Tauhī dì or al-Mau'd $\bar{u}^{\prime} i^{68}$ Is al-Turābī inspired by this division? It is possible because al-Turābī is a reformer $^{69}$ and modernist scientist who wants the Qur'ān as a guide and a solution for the people. ${ }^{70}$

What is new and can be said to be unique and superior to al-Turābī's interpretation is his serious effort in uniting and unifying. Not only between words and words, between verse and verse, sura and sura as it has been done by the scholars of interpretation. But far from that, al-Turābī is obsessed with uniting the guidance of the verses of the Qur'ān with real life. Uniting the text of revelation with natural phenomena.

Uniting the teachings that came down in the seventh century with the twentieth century and beyond. Uniting the vision of the Qur'ān as a book of life with human life, Muslim and non-Muslim, Arab and non-Arab in one unit under the power of Allah Almighty. In other words, al-Turābī wanted to convey his mission through his commentary. According to him, human goodness and peace will be achieved, if they are able to unite with the Qur'ān and the Qur'ān to unite with them in real life. ${ }^{71}$ So it is not surprising to say that the Al-Tafsìr Al-Tauhì $\bar{\imath}$ method for al-Turābī is the general framework of his thinking, both in the fields of science, politics, social and civilization.

As a human work, al-Tafsìr al-Tauhīdî, like other works of interpretation, will not be free from criticism and shortcomings. Among his shortcomings is that al-Turābī is trapped in rationalism by rejecting several authentic hadiths. It is very rare to refer to hadith if you refer only to its meaning or only indicate the final narrator. ${ }^{72}$ Even though al-Turābī claims that his interpretation is intended for all levels of society, in reality, the language used is difficult for those who do not know Arabics language adequately. This could be because of his influence as a philosophical and political thinker who is good at rhetoric. ${ }^{73}$

\section{Conclusion}

Based on the discussion above, it can be concluded that al-Tafsìr al-Tauhìd as the name implies contains two meanings. First; al-Tauhī $d$ as an interpretive paradigm in the sense of uniting humans and their activities as well as the universe in the guidance of the Qur'ān which is centered on the oneness of God. Second, as a form of

\footnotetext{
${ }^{68}$ al-Sayyid Muḥammad al-Bāqir al-Ṣadr, Muqaddimāt Fì Al-Tafs̄̄r Al-Maudhū 'i Lì Al-Qur'ān, 10.

${ }^{69}$ Mas'adah, "Epistemologi Pembaharuan Usul Fikih Hasan Turabi."

${ }^{70}$ Ibrahim, Esam Eltigani Mohamed and Zain, "Hasan Al-Turabi's Approach to Qur ' ā Nic Exegesis.”,

${ }_{71}$ Al-Turābī, Al-Tafsìr Al-Tauhī dì, 2004, 10-11.

${ }^{72}$ Al-Turābīi, 16.

${ }^{73}$ Berridge, Hasan Al-Turabi: Islamist Politics and Democracy in Sudan.
} 
interpretation which operationally can be categorized as a thematic interpretation of the al-Wahdah al-Maudü'iyyah model, namely the pattern of uniting related verses in one particular theme of a discussed letter. By using three systematic descriptions in each surah. Includes Khulāṣah Hady al-Sūrah; Tartīl al-Ma'āni and Umm al-ma'âni. Even though the application sometimes looks inconsistent.

The al-Tafsìr al-Tauhīdì tram used by al-Turābī is nothing new. Much earlier, alȘadr had introduced the tram under another name than al-Tafsì al-Maudu'i. But what al-Tauhī dḥi meant by al-Turābī was not al-Mau'i. But it is more accurately called al-Tafsīr al-Muṣhafi bi al-Wahdah al-Maudū'iyyah.

The peculiarity and advantages of al-Tafs̄ir al-Tauhīdíal-Turābì is's the ability to unite various related elements. Not only related to the correlation between verses or surahs but in a broader scope related to the correlation of human reality and the universe with the Qur'ān. So it is no exaggeration to say that al-Tafsìr al-Tauhī dì as a paradigm of thought for the whole project of al-Turābi civilization. In addition to the advantages, there are criticisms of him regarding rationality and his rejection of several authentic hadiths, giving the impression of leaving the thusriwäyah in the interpretation of the Qur'ān.

The vision of al-Tafsìr al-Tauhìd is to unite or unite the various elements of human life in the unity of the instructions of the Qur'àn, although there are some notes, it deserves to be appreciated. A spirit that can be actualized in a space of interpretation in Indonesia, which is rich in population diversity. A diversity similar to Sudan's conditions prompted al-Turābī to give birth to his work al-Tafs̄ir al-Tauhidit. It is a civilizational project to unite the diversity of the Sudanese population in harmony with the instructions of the Qur'ān with full tolerance

\section{REFERENCES}

Ahmad, Al-Amin HaJ Muhammad. Munāqasyah Al-Hādiah Li Ba'd Afkār Al-Duktūr Al-Turābi. Makaz al-Shaf al-Iliktruni, 1995.

Al-Ghazāli, Muhammad. Nahwa Tafs̄̄r Al-Maudhu'i Li Suar Al-Qur'ān. Kairo: Dār alSyurūq, 1995.

al-Sayyid Muhammad al-Bāqir al-Șadr. Muqaddimāt Fì Al-Tafsìr Al-Maudhū'i Lì AlQur'ān. Kuwait: Dār al-Taujīh al-Islāmi, 1980.

Al-Turābī, Ḥasan. Al-Tafsīr Al-Tauhī đì. Vol. 1. Bairut, Libanon: Dār al-Sāqi, 2004. Al-Tafsìr Al-Tauhīdî. 2nd ed. Bairut, Libanon: Dār al-'Arabiah li al-'Ulūm Nāsyirūn, 2011.

Ariski Aznor. "Kepentingan Mesir Menolak Meratifikasi Kesepakatan Cooperation Framework Agreement (CFA) Mengenai Aturan Pengelolaan Sungai Nil.” JOM 
FISIP VOL 2 NO 2 OKTOBER 2015 53, no. 9 (1981): 1689-99.

Bazmul, Muḥammad bin Sālim. Tahn̄̄r Fì Al-Tafsīr Al-Mauḍù'i Wa Al-Wahdah Al-

Maudū 'iyyah Li Al-Surah. Saudi Arabia: Kuliyyah al-Da'wah wa Ushuluddin

Jamiah Ummul Qura, n.d. https://www.radiosunna.com/uploads/6/6/1/7/6617650/

تحرير_التفسير_الموضوعي_و الوحدة_الموضوعية.pdf.

Berridge, W. J. Hasan Al-Turabi: Islamist Politics and Democracy in Sudan. Hasan Al-

Turabi: Islamist Politics and Democracy in Sudan, 2017. https://doi.org/10.1017/9781316848449.

Berridge, W J, and Hasan Islamist. "Reviews of Books The Spectre of Hasan Al-Turabi and Political Islam in Sudan" 89, no. May (2019): 398-401.

Cahyanti, Putri. “Analisis Konflik Sudan Dan Sudan Selatan.” Journal of International Relations 3 (2017): 84-95. http://ejournal-s1.undip.ac.id/index.php/jihi.

Fathina, Rasyidah. "Mahmoud Muhamed Taha: Redefinisi Konsep Nasakh Sebagai Pembentuk Syariat Humanis." Jurisdictie, 2012, 61-69. https://doi.org/10.18860/ j.v0i0.1593.

Hasan, Moh. Abdul Kholiq. "Freedom Of Religion In Rashid Rida' S Rasyid Ridha and Al Manar Tafsir Freedom of Religion in Perspective of Rasyid Ridha ' $\mathrm{s}$ Tafsir." Advances in Social Science, Education and Humanities Research (ASSEHR) 137, no. Icqhs 2017 (2018): 56-59. http://creativecommons.org/ licenses/by-nc/4.0/.

- "Interfaith Tolerance and Its Relevance to the Indonesian Diversity: A Study on Ibn 'Āshūr's Al-Taḥrīr Wa Al-Tanwīr." Ulumuna 22, no. 2 (2018): 333-62. https://doi.org/10.20414/ujis.v22i2.301.

—. Kaidah Kaidah Tafsir Al-Qur'ān. Sukoharjo: EFUDE PRESS IAIN Surakarta, 2013.

Hatta, Moh. "Pemikiran Hukum Islam Hasan Al-Turabi." Darussalam: Jurnal Pendidikan, Komunikasi, Dan Pemikiran Hukum Islam 7, no. 1 (2015): 189-99.

Hayati. "Perbandingan pendidikan antara negara mesir dan sudan." SERAMBI TARBAWI Jurnal Studi Pemikiran, Riset Dan Pengembangan Pendidikan Islam 01, no. 02 (2013): 395-412.

Helmy, Muhammad Irfan. "Kesatuan Tema Dalam Al-Qur'ān (Telaah HistorisMetodologis Tafsir Maudhu'iy).” Jurnal Ilmu Ushuluddin 19, no. 2 (2020): 64-80. https://doi.org/http://dx.doi.org/10.18592/jiiu.v19i2.3589.

Ibrahim, Esam Eltigani Mohamed and Zain, Ibrahim Mohamed. "Hasan Al-Turabi 's Approach to Qur' ā Nic Exegesis.” Intellectual Discourse, IIUM Press 22, no. 1 (2014): 53-71. http://journals.iium.edu.my/intdiscourse/index.php...

Jabaly, Ali. "Al-Fikr 'Inda Al-Turābiy; Qirāah Fī Muqaddimah Al-Tafsīr Al-Tauhīdy," 2019. https://omran.org/ar/الفكر _التوحيدي-عند_الترابي?language=en.

Kadir, Abdul. "Dakwah Dan Pembaharuan Pendidikan Islam Syaikh Ahmad Surkati." Jurnal Da'wah: Risalah Merintis, Da'wah Melanjutkan 2, no. 02 (2020): 1-20. https://doi.org/10.38214/jurnaldawahstidnatsir.v2i02.54. 
Karim, Abdul. "Tafsir At-Tauhîdi Karya Hasan At-Turâbi: Selingkung Baru Dalam Tafsir." Hermeneutik 13, no. 1 (2019): 34. https://doi.org/10.21043/hermeneutik. v13i1.5553.

Khilmi Hidayatulloh, Miftah. "Konsep Dan Metode Tafsir Tematik (Studi Komparasi Antara Al-Kumi Dan Mushthofa Muslim)." Al-Bayan: Jurnal Studi Ilmu AlQur'an Dan Tafsir 3, no. 2 (2019): 130-42. https://doi.org/10.15575/albayan.v3i2.4116.

Khoir, Tholkhatul. "Titik Temu Pemikiran Mahmoud Mohamed Thaha Dan Abdullahi Ahmed An-Na'im.' International Journal Ihya' 'Ulum Al-Din 18, no. 1 (2017): 65. https://doi.org/10.21580/ihya.17.1.1746.

Kumsa, A. "South Sudan Struggle for Independence, and It's Implications for Africa." RUDN Journal of Sociology 17, no. 4 (2017): 513-23. https://doi.org/10.22363/ 2313-2272-2017-17-4-513-523.

Makmun-Abha, Muhammad. "Kajian Kritis Atas Kitab Al-Tafsīr Al-Tawhīdī Karya Hāsan Al-Turābī.” Jurnal Studi Ilmu-Ilmu Al-Qựan Dan Hadis 15, no. 1 (2014): 2014.

Mas'adah. "Epistemologi Pembaharuan Usul Fikih Hasan Turabi." Jurnal Mahkamah 2, no. 1 (2017): 59. https://doi.org/10.25217/jm.v2i1.78.

Muhammad Abū Syuhbah. Al-Isrāiliyyāt Wa Al-Maudhu'āt Fì Kutub Al-Tafsìr. Kairo: Maktabah al-Sunnah, 1987.

Munawir. “The New Development Of Ulumul Qur' an ( The Methodological Studies of Asbab Al- Nuzul ).” Jurnal At-Tibyan: Jurnal Ilmu Alqur'an Dan Tafsir 5, no. 1 (2017): 74-89. https://doi.org/10.32505/tibyan.

Muslim, Musthafa. Mabāḥis Fì Al-Tafs̄̄r Al-Mauḍùì. Damaskus Syiria: Dār al-Fikr, 2000.

Nadhirah, Wardah. "Hermeneutika Al-Qur'ān Muhammad Al-Ghazali (Telaah Metodologis Atas Kitab Nahwa Tafsir Maudhu'i Li Suwar Al-Qur'ān Al-Karim).” Jurnal Studi Ilmu-Ilmu Al-Qur'ān Dan Hadis 15, no. 2 (2016): 237. https://doi.org/10.14421/qh.2014.15203.

Novyanti, Mira. "Reformasi Ushŭl Fikih Menurut Hasan Al-Turâbî Dan Kontribusi Pemikirannya Terhadap Dinamika Pemikiran Hukum Islam Kontemporer." Institut Agama Islam Negeri (IAIN) Antasari Banjarmasin, 2017. http://idr.uinantasari.ac.id/id/eprint/9121.

Ridlo, Ubaid. "Sinonim Dan Antonim Dalam Al-Quran." Jurnal Al Bayan: Jurnal Jurusan Pendidikan Bahasa Arab 9, no. 2 (2018). https://doi.org/10.24042/ albayan.v9i2.2253.

Supriadi, Cecep. "Relasi Islam Dan Negara: Wacana Keislaman Dan Keindonesiaan." KALIMAH 13, no. 1 (March 31, 2015): 217. https://doi.org/10.21111/ klm.v13i1.285.

Taufiq, Ahmad. "Pemikiran Abdullah Ahmed An-Naim Tentang Dekontruksi Syari'ah Sebagai Sebuah Solusi." International Journal Ihya' 'Ulum Al-Din 20, no. 2 
(October 2, 2018): 145. https://doi.org/10.21580/ihya.20.2.4044.

Wahiduddin. "Konflik Sudan Dan Jatuhnya Rezim Presiden Omar Bashir." Nady AlAdab 17, no. 1 (2020).

Zain, Ibrahim Mohamed. "Al-Fan Wa Qaḍāyā Al-Hawiyyah Al-Sudāniyyah: Qirāah Tậīliyyah F̄̄ Manhaj Al-Tafsīr Al-Tauhidī.” Al-Tajdíd 20, no. 39 (2016): 24981. 